
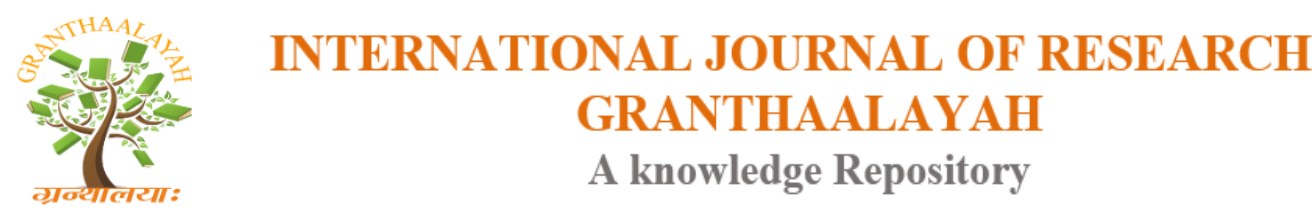

Management

\title{
BENCHMARKING LEADERSHIP IN LECTURERS' CAREERS DEVELOPMENT OF PRIVATE ISLAMIC HIGHER EDUCATION IN JAMBI PROVINCE
}

\author{
Professor Dr. H. Mukhtar ${ }^{1}$, Dr. Risnita ${ }^{2}$, Dr. Hj. Darwani ${ }^{3}$ \\ ${ }^{1}$ M.Pd, Professor at State Islamic University Sulthan Thaha Saifuddin, Jambi, Indonesia \\ ${ }^{2}$ M.Pd, Lecturer and Vice Director of Postgraduate State Islamic University Sulthan Thaha \\ Saifuddin, Jambi, Indonesia \\ ${ }^{3}$ M.Pd.I, Lecturer at State Islamic University Sulthan Thaha Saifuddin, Jambi, Indonesia
}

\begin{abstract}
The research aims to determine the strategies of Private Islamic Higher Education leaders in implementing the benchmarking concept in the Private Islamic Higher Education in Jambi Province. This research is qualitative research, with survey method carried out at the Private Islamic Higher Education in Jambi Province, namely at the STAI Syekh Maulana Qori Bangko, STIT Darul Ulum Sarolangun, and STAI Ma'arif Jambi. The research concludes that the strategy of the leaders of Private Islamic Higher Education in implementing the benchmarking concept is done through planning, implementation, and evaluating the implementation of the benchmarking concept. Based on the findings research, it can be built a theory that to develop lecturer careers can be done through benchmarking leadership roles carried out by leaders in Private Islamic Higher Education in Jambi Province.
\end{abstract}

Keywords: Benchmarking Leadership; Lecturer Career Development.

Cite This Article: Dr. H. Mukhtar, Dr. Risnita, and Dr. Hj. Darwani. (2018). "BENCHMARKING LEADERSHIP IN LECTURERS' CAREERS DEVELOPMENT OF PRIVATE ISLAMIC HIGHER EDUCATION IN JAMBI PROVINCE.” International Journal of Research Granthaalayah, 6(11), 138-152. https://doi.org/10.29121/granthaalayah.v6.i11.2018.1099.

\section{Introduction}

The effectiveness of the implementation of national education, both in terms of objectives, direction, budget, legality, and in terms of the ability of national education to provide superior and competitive services, and their ability to create a new generation of 'quality' from various perspectives and approaches. The weight of the educational roles carried out has caused the system of organizing our education units to be questioned, not to question existence, but its participation in the context of national development and its competition with global scale education. 
As a university, of course, it requires the involvement of various resources, for example human capital/human resource by utilizing those resources as added value for the university. Leadership aspects, quality of raw inputs (institutions and quality of students who enter), professional and accomplished lecturers, supporting facilities, utilization of information technology, will contribute to the realization of superior and competitive universities.

Islamic Higher Education in their dynamics experience a process of growing and developing according to changing times, and now Islamic Higher Education are aware of the nature of their development in the midst of the wider community. It must be admitted that Islamic Higher Education are an integral part of national development efforts.

Islamic higher education in the future have an increasingly important role. This increasingly important role arises as a result of changes in the situation with various results that have positive and negative implications for the development that is being and will be implemented. Therefore, fostering and developing Islamic tertiary institutions is very important to get attention and top priority in the effort to implement the Tri Dharma of Higher Education.

The effort to develop Private Islamic Higher Education requires cooperation with various parties, both with the community and the government. The reality of the diversity of educational institutions shows the existence of strengths as well as certain weaknesses that are owned by each of the existing Private Islamic Higher Education.

This benchmarking activity is carried out by an educational institution by visiting other institutions for the process of learning and exchanging information, which later results will be used as provisions to develop their own institutions. This strategy is very effective for formulating longterm goals through continuous improvement of performance.

\section{Literature Review}

\subsection{Leadership Concept}

Leadership is a process affecting group activities in the framework of formulating and achieving goals. ${ }^{1}$ A similar definition as stated by Fattah, that a leader is a person's ability to influence the behavior of others in his work by using the power he has. ${ }^{2}$

Karby in Muh. Hizbul Muflihin, states that leadership or leadership means guiding, meaning the process of managing organization, namely the process that takes place in the control of the organization. ${ }^{3}$ Sukarto also stated that leadership is all activities or actions to influence and encourage people in a joint effort to achieve goals. ${ }^{4}$ In addition, leadership can also be interpreted by the art of coordinating and encouraging people or groups to achieve their desired goals. Therefore, according to Ruchanah, leaders should be able to create dynamic changes in the

Siti, Ruchanah. Kepemimpinan Pendidikan Islam Dalam Perspektif Teologis. Cendekia Vol. 13 No. 1, Januari - Juni 2015), hal. 3.

Nanang, Fattah. Landasan Manajemen Pendidikan, (Bandung: Remaja Rosdakarya, 2004). hal. 88.

Muh. Hizbul Muflihin. Kepemimpinan Pendidikan: Kepemimpinan Pendidikan: Tinjauan terhadap Teori Sifat Tinjauan terhadap Teori Sifat

dan Tingkah- dan Tingkah-laku. Jurnal Pemikiran Alternatif Pendidikan. (INSANIA, Vol. 13, No. 1, Jan-Apr 2008) hal. 67-86.

Sukarto Indra Sukarto. Administrasi Pendidikan (Malang: IKIP Malang, 1986), hal. 110. 
organization rather than maintain the status quo. The changes referred to are more for purposes that are desired and shared, so they must be achieved together. ${ }^{5}$

The function of educational leadership as an educator according to Rohmat includes seven aspects, namely the achievement of educators, the ability to guide educators, the ability to guide employees, guide students, develop staff, the ability to learn and follow the development of science and technology, and the ability to give examples of teaching. ${ }^{6}$ Meanwhile, the function of educational leadership abilities as managers includes the ability to compile the program, compile staffing organizations in educational institutions, move staff, and the ability to optimize the power of educational institutions.

The function of educational leadership as an administrator includes the ability to manage the administration of teaching and learning activities as well as guidance and counseling, student affairs, staffing, finance, facilities and infrastructure, as well as aspects of the ability to manage mail administration. The function of educational leadership as educators, managers, administrators, supervisors, leaders, innovators, and motivators (EMASLIM) can be summarized into three main elements as follows: (1) Educational leadership as a manager includes functions as an administrator, and supervisor, (2) leadership education as a leader includes in it the function as an innovator and motivator, (3) educational leadership as an educator. ${ }^{7}$

Leslie and Lioyd looked at management functions that must be carried out by managers covering five aspects, namely (1) planning, including determining organizational goals to implement, and determining various things or strategies carried out to achieve goals; (2) organizing, consisting of grouping activities, determining activities, and the existence of authorities that will lead to activities to achieve goals; (3) staffing, including the determination of human resource needs, recruitment, selection, training, and development of human resources; (4) leading (direction) is the arrangement and distribution of human resources to achieve achievement that becomes the goal; (5) controlling includes measuring performance against predetermined goals, determining cases of irregularities and taking actions for repairs needed. ${ }^{8}$

Leaders (in this case educational leadership) according to the performance appraisal signs for educational institutions that have been established by the Ministry of Education, mention that educational leadership as a supervisor has five aspects of ability, namely: 1) Strong personality aspect; 2) Aspects of ability to know subordinates, 3) Aspects of understanding the vision and mission of educational institutions; 4) Aspect of decision making ability. ${ }^{9}$

From some of the leadership concepts mentioned above indicate that in a leadership there is a need for individual leadership abilities entrusted with lead responsibility, communication skills with subordinates/staff, the presence of individuals who are subordinates/staff, and the presence of subordinates/staff to leaders. These four things make leadership activities effective and efficient in achieving organizational goals.

\footnotetext{
Siti, Ruchanah, Loc.Cit, hal. 12.

Rohmat. Kepemimpinan Pendidikan, Jurnal Pemikiran Alternatif Kependidikan (INSANIA, Vol. 11, No. 1, Jan-Apr 2006), hal. 19-3. Ibid., hal. 19-3.

Rue, Leslie W. \& Byars, Lioyd L., Management: Skills and Application (San Francisco: McGraw-Hill, 2000), hal. 6.

Depdiknas Dirjen Pendidikan Dasar dan Menengah, Rambu-rambu Penilaian Kinerja Institusi Pendidikan (SLTP dan SMU) (Jakarta: Rineka Cipta, 2000), hal. 15.
} 


\subsection{Benchmarking Cconcept}

In addition to leadership, the development of universities, especially in Islamic education institutions must be carried out systematically, measurably and sustainably. One way to develop and improve the quality of service for educational institutions is to compare them with other educational institutions. This benchmarking process will have an impact on determining changes in the supporting factors for the productivity of these educational institutions such as: working hours, workloads, and even the salaries of employees and lecturers to be given. This is ultimately expected to spur the performance of these educational institutions to be better. The systematic and continuous measurement process is currently known as benchmarking.

Benchmarking is a collaboration between institutions by making direct observations. This benchmarking strategy was initially used in the business field to measure the performance of a company with other more advanced companies. ${ }^{10}$

Definition of benchmarking issued by American Productivity and Quality Center (APQC), benchmarking is a systematic and continuous measurement process, the process of measuring and comparing the continuity of business processes of an organization with leaders of business processes anywhere in the world, to obtain information that will help the company's efforts in improving its performance. ${ }^{11}$

Benchmarking is an approach that continuously measures and compares products and services, processes and practices against strict standards set by competitors or those who are considered superior in that field. ${ }^{12}$

This benchmarking activity is carried out by an educational institution by visiting other institutions for the process of learning and exchanging information, which later results will be used as provisions to develop their own institutions. This strategy is very effective for formulating longterm goals through continuous improvement of performance.

Benchmarking can be done internally and externally. Internal benchmarking is carried out within the tertiary institution itself, namely by conducting standard comparisons between study programs or work units in the higher education institutions themselves. External benchmarking is carried out for other institutions or universities, for study programs, both at home and abroad.

According to Adrie Putra, benchmarking is one strategy that can help companies to develop. ${ }^{13}$ According to Watson, as quoted by Ade, it also mentions that benchmarking is a continuous search and actual implementation of better practices that lead to superior competitive performance. This is in line with Camp's view, that benchmarking is a process of continuous measurement of our products, services and procedures towards our strongest competitors or other business entities

10 Michael Paulus dan Devie (2013). Analisa Pengaruh Penggunaan Benchmarking Terhadap Keunggulan Bersaing dan Kinerja Perusahaan. Business Accounting Review, Vol. 1, NO.2, 2013.

11 Adrie Putra, 2006. Strategi Benchmarking Sebagai Tolok Ukur Kinerja perusahaan. Forum Ilmiah Indonusa, Vol 3 No 3 September 2006 , hal. 11.

12 R. Wasisto Ruswidiono, Peningkatan Mutu dan Benchmarking Perguruan Tinggi dalam http://www.tsm.ac.id/MB/MB.3.diakses pada 8 Desember 2017.

13 Adrie Putra, Strategi Benchmarking Sebagai Tolok Ukur Kinerja perusahaan. Forum Ilmiah Indonusa, Vol 3 No 3 September 2006 , hal. 6. 
known as the best. Murad Salim said that benchmarking data can be used to evaluate and assess the financial health of a company. ${ }^{14}$

Benchmarking according to Anderson is a continuous process of measurement and comparing one or more business process companies with the best company in the business process, to obtain information that can help companies to identify and implement business process improvements. ${ }^{15}$ Benchmarking is used to regulate and improve the quality of education and academic standards. This benchmarking process is done through six steps, as follows:

- Determine what will be benchmarked

- Determine what will be measured

- Determine who the benchmark will be carried out

- Data collection by a team that has been formed

- Data analysis

- Formulate goals and plan of action. ${ }^{16}$

From some of the above meanings, it can be concluded that the purpose of benchmarking is to find the key or secret of success of another educational institution, then adapted, selected, and improved to be applied to educational institutions that carry out the benchmarking.

\subsection{Lecturer Career Development}

One of the most important factors in the world of education is career development for the instructors. In the kotenks the college pursuer is known as the dose. Therefore, to ensure the implementation and quality of education in higher education, the development of a doses career is a necessity.

Surya emphasized that a career is closely related to work, but has a broader meaning than work. Careers can be achieved through work that is planned and developed optimally and precisely, but work cannot always support career achievement. ${ }^{17}$ Thus work is an important stage in career development. Meanwhile, career development itself requires a long process, takes place early and is influenced by many factors of human life.

Munandir stated that a career is closely related to work and the matter of deciding a career is not a momentary event, but a long process and is part of the individual development process. ${ }^{18}$ Gibson and Mitchell explained that a career is the totality of one's work / occupational experience throughout his life. ${ }^{19}$ In the narrow sense of a career is the total amount of work experience / occupation someone in the public work category, such as a teacher, accounting, doctor, or sales. Milgram emphasized that career development is a long life process of crystallization of vocational identity. A wide variety of combinations of hereditary, physical, social-social, sociological,

\footnotetext{
14 Murad Salim Attiany. Competitive Advantage Through Benchmarking: Field Study of Industrial Companies Listed in Amman Stock Exchange. Journal of Business Studies Quarterly 2014, Volume 5, Number 4, hal. 12.

Andersen, B., \& Pettersen, P.The Benchmarking Handbook. London: Chapman \& Hall

Ibid.

Surya, Bimbingan Karier. Bandung: PPS UPI. Makalah tidak diterbitkan. 1988.

Munandir, Program Bimbingan Karier di Sekolah. Jakarta : PPTA -Ditjen Dikti Depdikbud. 1996.

9 Gibson, R. L. dan Mitchell, M.H. 1995. Intoduction to Counseling and Guidance, Englewood Cliffs. New Jersey : Prentice-Hall Inc.
} 
educational, economic, and cultural influences. In another section also mentioned that a career is a lifestyle. ${ }^{20}$

Referring to the description above, it can be understood that the teaching profession has a very strategic role in human development efforts, both in terms of economic affairs and in the fields of knowledge and technology. Therefore, the teaching profession must be developed in such a way that every lecturer has a clearer career direction.

Regarding the development of this career, everyone basically has a need for their lives. To meet their needs certainly requires effort through work. Every work activity carried out by an individual certainly expects results. If the results meet certain expectations then of course it will provide satisfaction in his work.

Job satisfaction is a general attitude of individuals who are individual about one's feelings about their work. ${ }^{21}$ In line with Robbins's view, Luthans argues that job satisfaction is an expression of employee satisfaction about how their work can provide benefits to the organization, which means that what is obtained in work meets what is considered important. ${ }^{22}$ Job satisfaction is considered as a result of the employee's experience in relation to his own values as desired and expected from his work. This view can be simplified that job satisfaction is an attitude of the individual and is feedback on his work.

According to the two factor theory, job satisfaction is two different things, meaning satisfaction and dissatisfaction with the job is not a continuous variable. Herzberg divides the situation that affects a person's feelings towards his work into two groups, namely the satisfiers group or motivator consisting of achievement recognition, responsibility, and the second is the group as a source of dissatisfaction or dissatisfiers consisting of work procedures, wages or salaries, relations between employees. Horald's opinions about factors that can lead to job satisfaction are as follows: 1) relationship factors among employees, including relationships between leaders and employees, physical conditions and work situations, suggestions from coworkers, 2) individual factors, which relate to people's attitudes on his work, people's age at work, gender, 3) external factors such as employee, recreation, education. ${ }^{23}$

While Newstrom and Davis regarding job satisfaction stated: "Job satisfaction is a set of favorable or unfavorable feelings and emotions with which employees view their work. Job satisfaction is an affective attitude - feeling of relative like or dislike toward something. (Feelings, Active Thoughts \& Behavior Intentions. ${ }^{24}$ "

The same view of job satisfaction according to Gibson and Ivancevich is stated as follows: "Job satisfaction is the attitude that individuals have about their jobs. It results from their perception of the jobs. While many dimensions have been associated with job satisfaction: pay, jobs, promotion opportunities, supervisors, co-workers". ${ }^{25}$

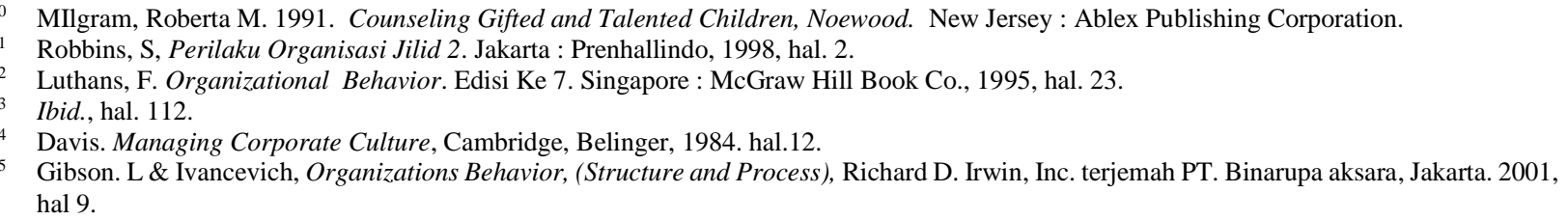


Based on the description of the theory above, the synthesis of job satisfaction is a pleasant feeling from the expression of acceptance of what he experienced in his organization / workplace while carrying out his duties and functions so that the organization's goals or institutions can be achieved effectively measured by a job satisfaction scale with a score of five points with indicators: (1) feel at home working (roles, work performance, task implementation, moral responsibility), (2) focus on work (3) work without knowing the time, (4) criticism of superiors is acceptable, (5 ) likes to help friends who have trouble.

\section{Research Methods}

This research is qualitative research, with a survey method carried out at Private Islamic Higher Education in Jambi Province, namely STAI Syekh Maulana Qori Bangko, STIT Darul Ulum Sarolangun, and STAI Ma'arif Jambi. To answer the existing problems, used data collection instruments in the form of observation, interviews, and documentation. The data obtained were analyzed by 1) organizing the data, 2) grouping by categories, themes and patterns of answers, 3) examining existing assumptions or problems with the data, 4) looking for alternative explanations for the data, and 5) writing research results.

Top of Form

Bottom of Form

\section{Results and Discussion}

\subsection{Strategies of Leaders in Implementing the Benchmarking Concept}

Leadership in Islamic Higher Education is expected to be able and skilled to influence the behavior of others, especially their subordinates, to think and act, to work with enthusiasm and trust in such a way that through positive behavior, they make a real contribution to achieving the vision and purpose of Islamic Higher Education.

To ensure the continuity of the education process, the leaders of Islamic Higher Education fulfill two equally important capacities, namely as managers of education in Islamic universities as a whole; and formal leaders of education in Islamic Higher Education.

In this capacity, Islamic Higher Education leaders are responsible for the success of conducting educational activities by implementing Islamic Higher Education administration with all its substance. In addition, it is also responsible for the quality and ability of existing human resources to carry out educational tasks.

Therefore, the leaders of Islamic universities as managers of education units have the duty to develop the performance of personnel (especially lecturers and employees) towards the expected professional competence.

In the capacity of a formal leader, Islamic Higher Education leaders are responsible for achieving educational goals through efforts to move subordinates towards achieving predetermined educational goals. In this case the campus leadership is tasked with carrying out the functions of 
leadership, both functions related to the achievement of educational goals and the creation of a conducive Islamic Higher Education climate for the implementation of effective and efficient teaching and learning processes.

Among the character of the leader is visionary leadership, visionary leadership is a leadership pattern that is intended to give meaning to the work and effort that needs to be done jointly by members of the institution/organization by giving direction and meaning to work and business based on a clear vision. ${ }^{26}$

From a management perspective, the strategy of the PTKIS leader in Jambi Province in implementing the benchmarking concept in general is good. This is based on basic management concepts, namely planning, implementation and evaluation. The three PTKIS leaders who were the subjects in this study already had a strategy to implement the benchmarking concept with that pattern. Thus it can be said that the strategy is good enough.

\subsubsection{Benchmarking Planning at PTKIS in Jambi Province}

Planning is the first step in a management process. In this step what is done is to select and determine the process that must be studied, identify the benchmarks of process performance, evaluate the organization itself, and determine the organization of objectives or to be compared. When linked in the context of education, in this first step an educational institution that will conduct benchmarking must understand the ins and outs of its own institutions and be able to identify what will be compared. Next, determine which institutions will be targeted for benchmarking studies.

Based on data from the results of the research that has been conducted, benchmarking planning has involved two important things, namely the planner and planning content. Planners are people involved in the planning process. In relation to university benchmarking planning, the elements of the plan are campus leaders, lecturers, employees, foundations and other stakeholders.

The planning content is everything that is planning material. Planning content consists of goals, suggestions, time, resources, current capabilities, measurable, specific, and so on. The results of the interview at PTKIS in the Jambi Province showed that the benchmarking planning process carried out by the PTKIS had involved elements of campus leadership, lecturers, employees, foundations and other stakeholders. The involvement of lecturers and students in campus planning related to the implementation of benchmarking has also been seen.

PTKIS in the Jambi Province environment in general has sought to involve various elements of the campus in implementing the campus progress planning. Planning the progress of the campus has involved leaders, lecturers, students, experts and so on. This indicates that the initial process of benchmarking planning has been going well.

Viewed from the point of view of the content of the plan (substance of the plan), in general PTKIS in the Jambi Province environment is already good. As mentioned above, planning content is all

26 Kartanegara," Strategi Membangun Eksekutif", dalam laman http://www.pln.co.id./fokus, diakses 2018. 
planning material. Planning content consists of goals, suggestions, time, resources, current capabilities, measurable, specific, and so on.

In addition, related to planning activities in the context of coaching and career development for lecturers, each PTKIS has different procedures and strategies. But clearly, every campus that is used as a setting in research has a strategy in developing and fostering the career of lecturers. The development and coaching of lecturers' careers in each campus is based on the rules and needs of each campus.

\subsubsection{Implementation of the Benchmarking Concept at PTKIS in Jambi Province}

The second step in the benchmarking process is the implementation of the plans that have been prepared. Implementation activities are activities to conduct primary and secondary research. In this step an investigation of secret disclosure of a particular process within a company is targeted. This second step can be done through discussion, compiling a written questionnaire or direct observation.

The benchmarking steps carried out by PTKIS in the Jambi Province followed the "Monash Process" model. This model establishes 13 steps in the benchmarking process, namely:

1) Define the mission of the institution, its strategic plan, and its critical factors.

2) Carry out education for employees, strive to form their commitment to change and the formation of a benchmarking team.

3) Choose the topic of benchmarking, identify key processes related to the topic, and design/measure the performance of the process.

4) Identify, carry out research on organizations with best practices (the most successful in the field of public services), or certain process processes and relationships.

5) Establish and implement standardization of data collection.

6) Carry out meetings with partners, measure and describe their performance.

7) Determine applicable performance gaps and identify opportunities for improvement opportunities.

8) Communicate the findings of benchmarking to employees.

9) Establish and implement agreements on implementation plans and implementation schedules.

10) Establish the necessary resources.

11) Carry out monitoring and make reports and start progress based on performance targets.

12) Perform calibration/measurement of benchmarking and recycle benchmarks.

13) Integrating benchmarking results into strategic plans (organizational/institutional strategic plan). ${ }^{27}$

These thirteen steps are the reference in the implementation or implementation of the benchmarking concept in each PTKIS in Jambi Province.

27 Crown Dirgantoro, Manajemen Strategik: Konsep, Kasus, dan Implementasi, (Jakarta: Grasindo, 2001), hal. 5-6. 


\subsubsection{Evaluation of the Implementation of the Benchmarking Concept at PTKIS in Jambi Province}

The implementation of benchmarking activities by PTKIS in Jambi Province is generally carried out by the team. Based on data from interviews with PTKIS leaders, it can be seen that after benchmarking activities, the team must make a written report that will be submitted to the relevant parties, such as the campus leadership and the foundation.

Making reports in writing and submitted to the leadership is intended so that the report can be followed up quickly by policy makers on campus. Thus, it can be understood that the evaluation of the implementation of the benchmarking concept was carried out jointly between the tasked team and the leadership and the foundation.

Thus, evaluation of benchmarking activities at PTKIS in the Jambi Province is carried out jointly. The evaluation activity involved the parties involved, namely the implementation team, the leadership team and the foundation. The evaluation activity itself is based on the final report from the implementing team. Thus it can be understood that the final quality of the evaluation process is very dependent on the quality of the report prepared by the team and the seriousness of the discussion by the parties concerned.

It can be said that related to the principles of implementing benchmarking activities, it is understood that PTKIS in the Jambi Province environment is already good. For this situation, it needs to be maintained and developed, so that the future will be better and better. With the quality of implementation of benchmarking indirectly will have a positive impact on improving the quality of PTKIS concerned.

\subsection{Constraints in Implementing Benchmarking}

As the saying goes, "there is no ivory that is not broken", nothing is perfect. Likewise with the benchmarking activities carried out by PTKIS in the Jambi Province environment. Even though the planning has been carefully arranged, the implementation of benchmarking activities has been carried out by the best teams of the campus, as well as evaluations involving the relevant parties but in the implementation there are still various obstacles.

The definite standard of human resource capability does not yet exist, as a result, information on the ability of teachers is based solely on predictions (predictions) which are subjective in nature. This has become a serious obstacle in Human Resources to calculate the potential of Human Resources for sure.

In addition to Human Resources issues, the obstacles faced by PTKIS in the Jambi Province environment were based on the results of interviews and continued document analysis with the leaders and benchmarking implementation teams obtained more complex information. The general description of the obstacles faced by PTKIS is illustrated as follows:

1) The benchmarking team is too internally focused so that the organization's vision becomes narrow. 
2) Benchmarking requires goals that are more specific and oriented on how (process), not on what (results).

3) Benchmarking requires patience, because it is a process of involvement that requires time.

4) The improper composition of the team needs to be involved with people who relate and carry out the daily organizational processes in the implementation of benchmarking. ${ }^{28}$

Meanwhile, based on the documentation of the results of the analysis of the report on benchmarking activities by the implementing team, it was also seen the same thing, as follows:

1) The schedule compiled by the implementation team of activities is less realistic.

2) The composition of the benchmarking team is still inaccurate, so there is still a need to involve people related to the implementation of benchmarking.

3) The team is still not able to choose the target campus as the best partner in carrying out benchmarking activities, with the main reason being inadequate financial support.

4) The implementation team does not precede benchmarking activities with preliminary research, so the target and target activities are unsatisfactory.

5) Inappropriate emphasis on the team is too imposing aspects of the collection and amount of data. Even though the most important aspect is the position itself.

6) Insensitivity to benchmarking partners provides access to observe the process and also provides time and personnel with the key to assisting the benchmarking process for organizations so that they must be respected and valued.

7) Limited top management support. Total support from top management is needed to start benchmarking, assist the preparation phase and ensure the achievement of the promised benefits. $^{29}$

In addition, related constraints especially in benchmarking are lack of motivation to adopt business practices, lack of adequate information on how to adapt and use them effectively and lack of capacity (resources or skills) in absorbing business practices. Most people have a tendency to learn, share experiences, and act better. This tendency is hindered by administrative, structural, cultural causes that negatively affect the entire organization.

In addition to mastery of the vision, mission and objectives, in developing the implementation team benchmarking activities must also consider the competencies, commitment and learning abilities of prospective teams. This is in line with the explanation given by Wahyu that there are many main aspects brought by individuals into a team, namely: 1) competency, expertise of team members in a particular midwife who can contribute to the achievement of team goals, 2) learning abilities of team members that directly influence team learning abilities, 3)commitment that can be given by team members in carrying out the tasks given, 4)team work, the ability to cooperate with each individual as team members, 5)collaboration, the ability to collaborate in teams and between teams, 6)communication, the level of communication skills of each team member, 7) trust, the level of trust in fellow team members, and 8) motivation that each team member has..$^{30}$

The main challenge related to the aspect of Team leadership is building a conducive culture and creating an atmosphere that supports teamwork. The recommended strategy for team leaders is to

\footnotetext{
${ }^{28}$ Document benchmarking kampus STAI SMQ Bangko.

${ }^{29} 2 \mathrm{Aa}$, document benchmarking kampus STAI SMQ Bangko.

$30 \quad$ Ibid., hal. 6.
} 
promote a view that recognizes that working together effectively is the expected standard of behavior.

\subsection{Benchmarking Formulation}

The benchmarking formulation is an initial process that has action bias, not just comparative studies of an educational process in other superior institutions. However, how can the benchmarking results be a benchmark for implementation in benchmarking institutions. Through a comprehensive benchmarking formulation, an educational institution will be able to make a benchmark in describing plans that are more specific to broader goals. ${ }^{31}$

Comprehensive benchmarking formulation is a planning activity oriented to broad insight to predict all possibilities that occur in the future. Formulation activities can not be separated from the role of campus leaders or universities as conceptors and movers of all campus resources.

Benchmarking Strategies in Educational Institutions Benchmarking follows a basic four-step pattern, in which the approach follows the fundamental quality method presented by Shewhart known as the Deming cycle or the PDCA cycle (plan - do - check - action). The Deming cycle consists of activities; plan, carry out plans, examine findings, and act. ${ }^{32}$

In formulating a comprehensive benchmarking strategy there are several things that need to be considered. First, oriented to the institution's vision and mission. An educational institution must make its vision and mission as a direction in making policies. The policies made must be responsive and responsive to the possibilities that occur in the future, namely not only educating students to be godly but also productive people. This is like the vision and mission of each PTKIS as explained above, the substance of which is the same, namely to realize Islamic graduates and also achieve. ${ }^{33}$

Second, understanding the characteristics of the institution itself. Each institution has different characteristics. This character can be a strength for an institution. Benchmarking strategies must be implemented for those who really understand the character / condition of the institution through an analysis of the internal environment and the external environment of the institution. The analysis that can be used is the SWOT analysis.

SWOT analysis is an analytical method for identifying internal and external factors of the organization. ${ }^{34}$ Internal factors are strengths and weaknesses, while external factors are opportunities and threats. The use of SWOT analysis is intended to determine where the organization is located.

Third, forming team-work. The benchmarking team is formed based on each individual's expertise in the field of study. Through the division of the team, it will be easier in the process of extracting information on the institution of the benchmark objectives so that it is more focused on certain fields of study.

\footnotetext{
${ }^{31}$ Didin Kurniadin dan Imam Machali, Manajemen Pendidikan..., hal. 177.

${ }^{32}$ Gregory H. Watson, Strategic Benchmarking..., hal. 4.

33 Document, STAI SMQ Bangko .

34 Didin Kurniadin dan Imam Machali, Manajemen Pendidikan:..., hal. 159.
} 
According to Armstrong and Baron in Wibowo, the characteristics of a goal that can be said to be good are one of them is team work-oriented. ${ }^{35}$ This is as the principle in designing the organizational structure, namely division of work. Stoner defines the division of labor as the division of all workloads into a number of tasks fairly and comfortably that can be carried out by individuals or groups. ${ }^{36}$ Division of work is an effort to divide work into small, simple jobs, in separate activities, where employees specialize in that field so productivity will increase through job specialization.

Fourth, the determination of superior institutions is the benchmark. Benchmarking strategies allow cooperation between the two parties to exchange information. That information will later be processed and used as a benchmark for the development of schools that carry out benchmarking studies. Because basically the schools that conduct the study are looking for future campus formats. For this reason, superior institutions that are the goal of benchmarking are campuses that play the role as leaders.

Referring to the situation and conditions as described above, it is better for the campus (PTKIS) to choose a benchmarking partner at an advanced institution, or at least accredited "A", both institutionally and specifically in service. According to Watson there are several criteria in choosing benchmarking partners, including: 1) type of organization, 2) organizational culture, 3) organizational structure, 4) potential performance, 5) reputation, 6) quality of graduates, 7) partnership reach, 8) system management, and 9) the development of technology. ${ }^{37}$

Fifth, determining the topic of benchmarking. Benchmarking topics are generally determined by adjusting the conditions in the institutions themselves and benchmarking partner institutions. Usually these considerations are taken in terms of the uniqueness of the institution which is expected to provide new information that has never been published. At this stage preparation needs to be in the form of guidelines for interviews, questionnaires, or documentation. ${ }^{38}$

Benchmarking partners also need to know the information they want to find, so that cooperation can really benefit both parties. Discussion topics can be taken from the results of the SWOT analysis that has been carried out. Thus, at the stage of formulation the benchmarking strategy must be drafted as well as possible (comprehensive) so that the implementation of benchmarking studies can run optimally.

The formulation of a comprehensive benchmarking strategy requires the role of the leadership of PTKIS as a drafter. Because basically the selection of this strategy arises from the campus leadership. So that in the planning / formulation you must really think about what the goals and expectations are for implementing this benchmarking strategy. First the campus leadership must have a firm vision by instilling a commitment to change towards better and identifying a clear job description for subordinates who are members of this benchmarking team.

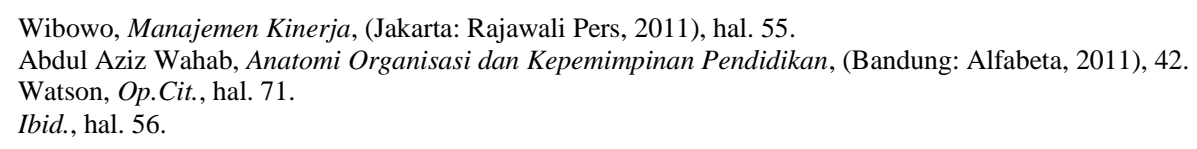




\section{Conclusion}

The results of research on Benchmarking Leadership in Lecturers' Careers Development of Private Islamic Higher Education in Jambi Province as follows:

1) In the framework of fostering lecturers through benchmarking activities of PTKIS leaders in the Jambi Province, several strategies were implemented. The strategy developed by PTKIS leaders in the Jambi Province is to follow the steps that are already good, namely to carry out activities: 1) Benchmarking planning, 2) Implementation of the benchmarking concept, and 3) Evaluation of the implementation of the benchmarking concept.

2) Some of the obstacles faced by PTKIS leaders in implementing the benchmarking concept are as follows: 1) The benchmarking team is too internally focused so that the organization's vision becomes narrower, 2) Benchmarking requires goals that are more specific and oriented to (process), not what (results ), 3) Benchmarking requires patience, because it is a process of engagement that requires time, and 4) The composition of the team that is not appropriate needs to be involved with people who relate and run the organizational process daily in implementing benchmarking.

3) The benchmarking formulation in developing lecturers' careers in the Private Islamic College in Jambi Province by PTKIS leaders, namely: 1) oriented to the institution's vision and mission, 2) understanding the characteristics of its own institutions, 3) forming benchmarking teamwork, 4) determine the superior institutions that become the benchmark, 5) determine the topic of benchmarking.

\section{References}

[1] Adrie, Putra. Strategi Benchmarking Sebagai Tolok Ukur Kinerja perusahaan. Forum Ilmiah Indonusa, Vol 3 No 3 September 2006.

[2] Andersen, B., \& Pettersen, P. The Benchmarking Handbook. London: Chapman \& Hall. 1996.

[3] Cook, Sarah. Practical Benchmarking: A Manager's Guide to Creating Competitive Advantage. Kogan Page Ltd, 1995.

[4] Crown Dirgantoro, Manajemen Strategik: Konsep, Kasus, dan Implementasi, Jakarta: Grasindo, 2001.

[5] Davis. Managing Corporate Culture, Cambridge, Belinger, 1984.

[6] Gibson. L \& Ivancevich, Organizations Behavior, (Structure and Process), Richard D. Irwin, Inc. terjemah PT. Binarupa aksara, Jakarta. 2001.

[7] Hendyat Soetopo, Perilaku Organisasi: Teori dan Praktik di Bidang Pendidikan, Bandung: Remaja Rosdakarya, 2012.

[8] Kartanegara, Strategi Membangun Eksekutif', dalam laman http://www.pln.co.id./fokus, diakses 2018.

[9] Luthans, Fred. Perilaku organisasi, Edisi sepuluh, Penerbit ANDI Yogyakarta, 2006.

[10] Michael Paulus dan Devie. Analisa Pengaruh Penggunaan Benchmarking Terhadap Keunggulan Bersaing dan Kinerja Perusahaan. Business Accounting Review, Vol. 1, No.2, 2013.

[11] Milgram, Roberta M., Counseling Gifted and Talented Children, Noewood. New Jersey : Ablex Publishing Corporation. 1991

[12] Muh. Hizbul Muflihin. Kepemimpinan Pendidikan: Tinjauan terhadap Teori Sifat Tinjauan terhadap Teori Sifat dan Tingkah laku. Jurnal Pemikiran Alternatif Pendidikan. Insania, Vol. 13, No. 1, Jan-Apr 2008.

[13] Munandir. Program Bimbingan Karier di Sekolah. Jakarta : PPTA -Ditjen Dikti Depdikbud. 1996. 
[14] Murad Salim Attiany. Competitive Advantage Through Benchmarking: Field Study of Industrial Companies Listed in Amman Stock Exchange. Journal of Business Studies Quarterly, Volw ume 5, Number 4, 2014

[15] Nanang, Fattah. Landasan Manajemen Pendidikan, Bandung: Remaja Rosdakarya, 2004.

[16] Robbins, SP. Perilaku Organisasi, (Edisi kesepuluh; alih bahasa Benyamin Molan, Edisi Bahasa Indonesia; PT.Mancanan Jaya Cemerlang, Indonesia 2006

[17] Rohmat, Kepemimpinan Pendidikan, Jurnal Pemikiran Alternatif Kependidikan INSANIA, Vol. 11, No. 1, Jan-Apr 2006.

[18] Rue, Leslie W. \& Byars, Lioyd L., Management: Skills and Application (San Francisco: McGrawHill, 2000.

[19] R. Wasisto Ruswidiono, Peningkatan Mutu dan Benchmarking Perguruan Tinggi dalam http://www.tsm.ac.id/MB/MB.3.diakses pada 8 Desember 2017.

[20] Sondang P., Manajemen Sumber Daya Manusia. Jakarta, Bumi Aksara., 1999.

[21] Siti Ruchanah. Kepemimpinan Pendidikan Islam Dalam Perspektif Teologis. Cendekia Vol. 13 No. 1, Januari - Juni 2015.

[22] Sukarto Indra Sukarto. Administrasi Pendidikan (Malang: IKIP Malang, 1986.

[23] Surya. Bimbingan Karier. Bandung: PPS UPI. Makalah tidak diterbitkan, 1988.

[24] Syafi'i. Rasio Total Benchmarking Sebagai Indikator Tingkat Kepatuhan Wajib Pajak (Studi Kasus Pada Pt. Semen Gresik. Jurnal WIGA Vol. 3 No. 1, Maret 2013

[25] Tatterson, J.G. Benchmarking Basics: Looking for A Better Way. Manlow Park, Ca: Christ Publication. 1996.

[26] Venetucci, R., Benchmarking: A Reality Check for Strategy and Performance. Production and Inventory Management Journal, 33(4), 32-39. 1992.

[27] Watson, G. Strategic Benchmarking Reloaded With Six Sigma: Improving Your Company's Performance Using Global Best Practices. New Jersey, USA: John Wiley \& Sons Inc 2007.

[28] Wibowo, Manajemen Kinerja, Jakarta: Rajawali Pers, 2011.

[29] Zuhairini, dkk., Filsafat Pendidikan Islam. Jakarta: Bumi Aksara, 1995. 